\title{
Analyzing the Influence of Biomass and Vegetation Type to Soil Organic Carbon* \\ - Study on Seoseoul Lake Park and Yangjae Citizen's Forest - \\ Tanaka Riwako $^{\text {() }} \cdot$ Kim, Yoon-Jung ${ }^{1)} \cdot$ Ryoo, Hee-Kyung ${ }^{1)}$ and Lee, Dong-Kun ${ }^{2)}$ \\ ${ }^{1)}$ Graduate School of Seoul National University, \\ ${ }^{2)}$ Department of Landscape Architecture and Rural System Engineering, Seoul National University.
}

\section{바이오매스량과 식생구조가 토양 탄소함유량에 미치는 영향 분석*}

- 서서울호수공원과 양재 시민의 솦을 대상으로 -

\author{
Tanaka Riwako ${ }^{1)} \cdot$ 김윤정 $^{1)} \cdot$ 류희경 ${ }^{1)} \cdot$ 이동근 $^{2)}$ \\ 1) 서울대학교 대학원 · ${ }^{2)}$ 서울대학교 조경·지역시스템공학부
}

\begin{abstract}
Identification of methods to optimize the growth of a plant community, including the capacity of the soil to further sequester carbon, is important in urban design and planning. In this study, to construct and manage an urban park to mitigate carbon emissions, soil organic carbon of varying biomass, different park construction times, and a range of vegetation types were analyzed by measuring aboveground and belowground carbon in Seoseoul Lake Park and Yangjae Citizen's Forest. The urban parks were constructed during different periods; Seoseoul Lake Park was constructed in 2009, whereas Yangjae Citizen's Forest was constructed in 1986. To identify the differences in soil organic carbon in various plant communities and soil types, above and belowground carbon were measured based on biomass, as well as the physical and chemical features of the soil. Allometric equations were used to
\end{abstract}

\footnotetext{
* The Korea Environmental Industry and Technology Institute (KEITI) of the Korea government (ME) supported this study (Grant No. 416-111-015).

First author: Tanaka Riwako, Graduate School, Seoul National University, Tel : +82-2-880-4885, E-mail : shiningcactus@ @otmail.com

Corresponding author : Lee, Dong-Kun, Department of Landscape Architecture and Rural System Engineering, Seoul National University,

Tel : +82-2-880-4875, E-mail : dklee@ snu.ac.kr

Received : 12 January, 2014. Revised : 21 February, 2014. Accepted : 17 February, 2014.
} 
measure biomass. Soil total organic carbon (TOC) and chemical properties such as $\mathrm{pH}$, cation exchange capacity (CEC), total nitrogen (TN), and soil microbes were analyzed. The analysis results show that the biomass of the Yangjae Citizen's Forest was higher than that of the Seoseoul Lake Park, indicating that older park has higher biomass. On the other hand, TOC was lower in the Yangjae Citizen's Forest than in the Seoseoul Lake Park; air pollution and acid rain probably changed the acidity of the soil in the Yangjae Citizen's Forest. Furthermore, TOC was higher in mono-layered plantation area compared to that in multi-layered plantation area. Improving the soil texture would, in the long term, result in better vegetation growth. To improve the soil texture of an urban park, park management, including $\mathrm{pH}$ control by using lime fertilization, soil compaction control, and leaving litter for soil nutrition is necessary.

Key Words : Carbon sequestration, Urban park, Plantation layer, Park construction time.

탄소축적량 증진을 위한 도시공원 설계 및 계획에 적합한 식재구조와 토양 관리방법에 대한 분석 이 필요하다. 본 연구에서는 탄소저감에 기여하는 도시공원 설계와 관리를 위하여, 서서울호수공원 과 양재시민의 숲을 대상으로 바이오매스량과 공원조성 시기 및 식재구조가 다른 조사구에서의 토양 탄소함유량을 지상부 지하부 탄소저장량의 측정을 통해 분석하였다. 대상 도시공원으로 조성시기가 다른 서서울호수공원(2009년)과 양재 시민의 숲(1986년)을 선정하였다. 식생과 토양 특성에 따른 토 양 탄소함유량의 차이를 분석하기 위하여, 바이오매스량과 토양의 물리적 - 화학적 특성 측정을 통해 지상부 - 지하부 탄소저장량을 분석하였다. 바이오매스량 측정에는 상대생장식을 적용하였으며, 토 양에 관해서는 토양 탄소함유량(TOC)과 $\mathrm{pH}$, 양이온치환용량(CEC), 전질소량(TN), 토양 총 균수와 같은 화학적 특성을 측정하였다. 이 결과, 바이오매스량은 양재 시민의 숲이 서서울호수공원보다 높 아, 조성된 지 오래된 공원의 바이오매스량이 높은 것으로 나타났다. 한편, 토양 탄소함유량은 양재 시민의 숲이 서서울호수공원 보다 낮았으며, 이는 양재시민의 숲에서의 대기오염과 산성비 노출에 의한 토양의 산성화 진행에 따른 영향 때문인 것으로 분석되었다. 또한, 토양 탄소함유량은 단층식재 지가 다층식재지 보다 높은 것으로 나타났다. 장기적 시점에서 볼 때, 토양 개선은 식생 생장을 도모 한다. 따라서 도시공원의 토양 특성 개선을 위하여, 석회성 비료 시비에 의한 $\mathrm{pH}$ 조절과 답압 제어 및 낙엽층 방치에 의한 토양 양분 증진을 통한 공원관리가 필요하다.

키워드 : 탄소 격리, 도시공원, 식재 구조, 공원 조성 시기.

\section{INTRODUCTION}

Carbon sequestration through the process of photosynthesis plays an important role in the management of an ecosystem (Henry et al., 2009). Carbon sequestration, which is generally high in green areas, therefore, has been suggested as an effective method of addressing the problem of 
elevated atmospheric $\mathrm{CO}_{2}$ concentrations and contributing toward the prevention of global warming (Watson, 2000).

Urban trees, such as those near the streets and in parks, and soil play fundamental roles in an urban ecosystem, specifically in terms of carbon sequestration (Nowak et al., 2006). Several studies have shown methods of effective sequestration of carbon in an urban ecosystem (Baschak and Brown, 1995). Urban ecosystems have been recognized as key features that can enhance the structure, function, and services of a specific locale and requires extensive design and planning (Hunter M., 2011).

The date of establishment of an urban park largely influences the extent of carbon sequestration that occurs at the site. Several ecologists have previously shown that larger biomass has greater capacity to accumulate carbon in the soil (Zhang et al., 2011). This correlation is mainly attributable to the ability of biomass to sustain the levels of organic matter in the soil, including soil organic carbon (Zhang et al., 2011). Although studies conducted by Nowak et al. (2006) and Hutson (2003) have identified the influence of age, composition, and history of forest to carbon sequestration, the mechanism of carbon sequestration in an urban park remains unclear (Hunter M., 2011).

Therefore, to determine the influence of biomass maturity on carbon accumulation in urban park soil, this study addressed two questions: 1) Does biomass maturity influence the level of total organic carbon (TOC) in urban park soil? and 2) Do TOC levels in urban parks change over time or structural diversity?

We assumed that differences in the establishment date of urban parks would reflect variations in the age and maturity of its constituent plant communities. Thus, we selected two urban parks Seoseoul Lake Park and Yangjae Citizen's Forest, which represent the new and old parks in Seoul, respectively. Assessment of both the parks, considering its date of establishment, may help identify differences in planting design, soil features, and levels of accumulated carbon in the soil. Biomass, soil TOC, and other chemical and physical properties of the soil in Seoseoul Lake Park and Yangjae Citizen's Forest as well as the mono-layered and multi-layered plantation areas were analyzed. The information generated in this study may be utilized in urban park construction and management for climate change mitigation.

\section{STUDY SITES}

The study sites were Seoseoul Lake Park and Yangjae Citizen's Forest, as shown in Table 1. Seoseoul Lake Park is located in Yangcheon-gu, Seoul, with an area of 217,946 $\mathrm{m}^{2}$; Yangjae Citizen's Forest is located in Seocho-gu, Seoul, covering 258,992 $\mathrm{m}^{2}$. Seoseoul Lake Park was constructed in October 2009, whereas the Yangjae Citizen's Forest was developed in November 1986. The rationale in selecting these two urban parks was to utilize the time of construction as a variable in identifying differences in soil characteristics. The two parks, thus, reflect a 23 year difference in establishment time.

A retrospective review of the parks' previous land use shows that the area where the current Seoseoul Lake Park stands was originally a water purification plant since 1979, supplying tap water to Seoul residences until it ceased its operation in 2003. The area where the Yangjae Citizen's Forest now stands used to be a farmland and 
Table 1. Soil information of the study sites.

\begin{tabular}{c|c|c}
\hline \hline & Seoseoul Lake Park & Yangjae Citizen's Forest \\
\hline Date of opening & October 26, 2009 & November 30, 1986 \\
\hline Area & $225,368 \mathrm{~m}^{2}$ & $258,992 \mathrm{~m}^{2}$ \\
\hline Previous land use & Water purification plant (1959-2003) & Farmland and village (near memorial hall) \\
\hline $\begin{array}{c}\text { Soil covering } \\
\text { (at the time of construction) }\end{array}$ & None & $\begin{array}{l}\text { Covered by a mixture of garbage and } \\
\text { mountain soil, with depths ranging from } \\
30 \sim 60 \mathrm{~cm} \text { in flat areas, 1 2 } \mathrm{m} \text { in } \\
\text { molded areas (Jang, 1995) }\end{array}$ \\
\hline $\begin{array}{c}\text { Soil covering } \\
\text { (during management) }\end{array}$ & None & None \\
\hline Fertilization & $\begin{array}{l}\text { Type of fertilizer: Humus } \\
\text { Amount of fertilizer: Depends on the size } \\
\text { of trees (e.g., 20 kg / 20 m, 2-3 kg for shrubs) } \\
\text { Season of application: Every spring and fall } \\
\text { Application method: Deep placement or } \\
\text { sub-surface placement }\end{array}$ & None \\
\hline
\end{tabular}

village. During its construction, the soil was covered with garbage and mountain soil, with depths of $30 \sim 60 \mathrm{~cm}$ in flat areas and $1 \sim 2 \mathrm{~m}$ in molded areas, whereas that of Seoseoul Lake Park was not. Yangjae Citizen's Forest, however, does not utilize fertilizers in its park management, whereas Seoseoul Lake Park uses humus fertilizer, depending on the size of the trees (e.g., $20 \mathrm{~kg}$ of fertilizer per $20 \mathrm{~m}$ tall tree).

\section{METHODS}

The types of vegetation and soil fertility were analyzed through a literature review. Vegetation types were divided into mono-layered plantation area and multi-layered plantation area with shrub area. Three study plots $(5 \times 5 \mathrm{~m})$ were set for each vegetation type at both Seoseoul Lake Park and Yangjae Citizen's Forest. The plots were widely distributed across the park because this study was intended to reflect the park's general soil characteristics.
To gather information on the vegetation in each plot, tree diameter at breast height (DBH), tree height, and shrub width were measured on August 28, 2013. Above and belowground allometric was analyzed by using allometry equations (Table 2). Allometric equations were obtained from previous reports and applied to each plant species. When equations with urban tree weight were available, these were applied.

Intact soil cores were collected at three points at a depth of $10 \sim 20 \mathrm{~cm}$ soil using $100 \mathrm{~mL}$ soil core samplers and bulk density was measured. Soils were collected at three points in each study plot at a depth of $0 \sim 30 \mathrm{~cm}$ by using an auger. TOC were measured by using the Walkley-Black wet oxidation assay. $\mathrm{pH}$ was measured by using a glass electrode (soil: $0.01 \mathrm{MCaCl}_{2}$ at 1: 5), total nitrogen (TN) was measured using a Kjeltec Auto 1035/1038 System. Cation exchange capacity (CEC) was measured by saturating soils with 1 $\mathrm{N} \mathrm{NH}_{4} \mathrm{OAc}$ (pH 7.0), washed with excess ethanol and quantified. Soil microbes were analyzed 
Table 2. Allometric equations (V: Trunk tree volume (kg), D: DBH $(\mathrm{cm})$, Y: Carbon stocks $(\mathrm{kgC}), \mathrm{A}:$ Area $\left(\mathrm{m}^{2}\right)$ ).

\begin{tabular}{|c|c|c|c|c|c|}
\hline \multirow{3}{*}{ Species } & \multicolumn{4}{|c|}{ Allometric equations } & \multirow{3}{*}{ Reference } \\
\hline & \multicolumn{2}{|c|}{$V\left(m^{3}\right)=a D^{b}$} & \multirow{2}{*}{$\begin{array}{c}\text { Biomass } \\
\text { density } \\
\left(\mathrm{kg} / \mathrm{cm}^{2}\right)\end{array}$} & \multirow{2}{*}{ Factors } & \\
\hline & $a$ & $b$ & & & \\
\hline Zelkova serrata (Sawleaf zelkova) & 0.0006 & 1.73624 & 564 & \multirow{5}{*}{$\begin{array}{c}\text { Biomass expansion } \\
\text { factors: } 1.45 \\
\text { Urban tree weight: } \\
0.8 \\
\text { Aboveground-root } \\
\text { weight: } 0.26 \\
\text { Biomass } \\
\text { conversion factor: } \\
0.5\end{array}$} & \multirow{5}{*}{$\begin{array}{c}\text { Korea Forest } \\
\text { Research institute } \\
\text { (2012) }\end{array}$} \\
\hline $\begin{array}{l}\text { Prunus sargentii (Sargent cherry), } \\
\text { Prunus serrulata var. spontanea } \\
\text { (Cherry blossoms), } \\
\text { Chaenomeles sinensis (Chinese quince) }\end{array}$ & 0.00009 & 2.17249 & 514 & & \\
\hline Fraxinus rhynchophylla (Ash tree) & 0.00015 & 2.1457 & 605 & & \\
\hline $\begin{array}{l}\text { Acer palmatum thunb (Japanese maple), } \\
\text { Acer pseudo-sieboldianum (Trident maple) }\end{array}$ & 0.00016 & 2.02375 & 562 & & \\
\hline Ginkgo biloba (Ginkgo) & 0.00022 & 2.16083 & 371 & & \\
\hline Other broad-leaved trees & \multicolumn{4}{|c|}{$Y=-2.3463+2.4136 D$} & $\begin{array}{c}\text { Korea Forest } \\
\text { Research institute } \\
(2012)\end{array}$ \\
\hline Other coniferous trees & \multicolumn{4}{|c|}{$Y=-2.7127+2.4581 D$} & Jo and Ahn (2000) \\
\hline Broadleaf shrubs & \multicolumn{4}{|c|}{$Y=0.457 A$} & Jo et al. (1995) \\
\hline
\end{tabular}

using a yeast extract medium. In the case of TOC, soil samples from each collection point were used for the analysis. However, for the analysis of $\mathrm{pH}, \mathrm{TN}, \mathrm{CEC}$, and microbe, the mixture of soil samples from three points of each plots were used.

\section{RESULTS AND DISCUSSION}

\section{Aboveground and belowground biomass}

\section{1) Features of the plant community}

The plant species included in our survey are presented in Table 3. The dominant plant species in Seoseoul Lake Park were Ilex serrata (japanese winterberry) and Prunus serrulata var. spontanea (cherry blossom). In Yangjae Citizen's Forest, Fraxinus rhynchophylla (ash tree), Aesculus turbinata (horse chestnut), Ginkgo biloba (ginkgo), and Zelkova serrata (sawleaf zelkova) were the dominant species. Physical properties of the surveyed vegetation are shown in Table 4. DBH and tree height in Yangjae Citizen's Forest were higher than that of Seoseoul Lake Park, reflecting differences in vegetation type. The average DBH of the mono-layered plantation area in Seoseoul Lake Park was $15.85 \mathrm{~cm}$, whereas the multi-layered plantation area showed an average DBH of $14.05 \mathrm{~cm}$. In the Yangjae Citizen's Forest, the mono-layered plantation area and the multi-layered plantation area showed a DBH of $18.5 \mathrm{~cm}$ and $29.53 \mathrm{~cm}$, respectively. In Seoseoul Lake Park, the average tree height in the mono-plantation area was $6.91 \mathrm{~m}$, whereas that of the multi-layered plantation area was $5.63 \mathrm{~m}$. The average tree height in the Yangjae Citizen's Forest was $12.62 \mathrm{~m}$ and $15.5 \mathrm{~m}$ in the mono and multi-layered plantation areas, respectively. The results showed that the two parks that were established at different times showed different plant community maturities. 
Table 3. Surveyed plant species.

\begin{tabular}{|c|c|c|c|c|}
\hline & Vegetation type & Plot No. & Tall three species & Shrub species \\
\hline \multirow{6}{*}{$\begin{array}{c}\text { Seoseoul } \\
\text { Lake Park }\end{array}$} & \multirow{3}{*}{$\begin{array}{l}\text { Mono-layered } \\
\text { plantation }\end{array}$} & 1 & Ulmus davidiana & \\
\hline & & 2 & $\begin{array}{l}\text { Ulmus davidiana, } \\
\text { Chaenomeles sinensis }\end{array}$ & \\
\hline & & 3 & $\begin{array}{l}\text { Chaenomeles sinensis, } \\
\text { Acer pseudo-sieboldianum }\end{array}$ & \\
\hline & \multirow{3}{*}{$\begin{array}{l}\text { Multi-layered } \\
\text { plantation }\end{array}$} & 1 & $\begin{array}{l}\text { Prunus serrulata var. spontanea, } \\
\text { Castanea crenata }\end{array}$ & $\begin{array}{l}\text { Sorbaria stellipilla var. typica } \\
\text { SCHNEID }\end{array}$ \\
\hline & & 2 & Ilex serrata & $\begin{array}{l}\text { Rhododendron yedoense var. } \\
\text { poukhanense (Lev.) Nakai }\end{array}$ \\
\hline & & 3 & $\begin{array}{l}\text { Cercidiphyllum japonicum, } \\
\text { Acer platanoides Linnaeus }\end{array}$ & $\begin{array}{l}\text { Aster maackii, } \\
\text { Rhododendron indicum, } \\
\text { Taxus cuspidata var. nana }\end{array}$ \\
\hline \multirow{6}{*}{$\begin{array}{l}\text { Yangjae } \\
\text { Citizen's } \\
\text { Forest }\end{array}$} & \multirow{3}{*}{$\begin{array}{l}\text { Mono-layered } \\
\text { plantation }\end{array}$} & 1 & Fraxinus rhynchophylla & \\
\hline & & 2 & Aesculus turbinata & \\
\hline & & 3 & Zelkova serrata & \\
\hline & \multirow{3}{*}{$\begin{array}{l}\text { Multi-layered } \\
\text { plantation }\end{array}$} & 1 & $\begin{array}{l}\text { Ginkgo biloba, } \\
\text { Acer palmatum thunb }\end{array}$ & $\begin{array}{l}\text { Fraxinus rhynchophylla, } \\
\text { Cornus alba cv. Aurea }\end{array}$ \\
\hline & & 2 & Ginkgo biloba & Rhododendron schlippenbachii \\
\hline & & 3 & $\begin{array}{l}\text { Zelkova serrata, } \\
\text { Prunus sargentii }\end{array}$ & $\begin{array}{l}\text { Rhododendron yedoense var. } \\
\text { poukhanense (Lev.) Nakai }\end{array}$ \\
\hline
\end{tabular}

Table 4. Physical properties of the vegetation.

\begin{tabular}{|c|c|c|c|c|c|}
\hline & Vegetation type & Plot No. & Height (m) & DBH $(\mathrm{cm})$ & Canopy enclosure (\%) \\
\hline \multirow{6}{*}{$\begin{array}{c}\text { Seoseoul } \\
\text { Lake Park }\end{array}$} & \multirow{3}{*}{$\begin{array}{c}\text { Mono-layered } \\
\text { plantation }\end{array}$} & 1 & $6.5 \pm 0.5$ & $9.3 \pm 0.7$ & $5 \sim 25$ \\
\hline & & 2 & $6.5 \pm 0.5$ & $13.6 \pm 3.5$ & $26 \sim 50$ \\
\hline & & 3 & $7.8 \pm 1.3$ & $24.7 \pm 6.9$ & $26 \sim 50$ \\
\hline & \multirow{3}{*}{$\begin{array}{c}\text { Multi-layered } \\
\text { plantation }\end{array}$} & 1 & $6 \pm 4$ & $18.1 \pm 6.1$ & $75 \sim 100$ \\
\hline & & 2 & $5.5 \pm 1$ & $11.9 \pm 17$ & $75 \sim 100$ \\
\hline & & 3 & $5.4 \pm 3.6$ & $12.2 \pm 0.8$ & $51 \sim 75$ \\
\hline \multirow{6}{*}{$\begin{array}{c}\text { Yangjae } \\
\text { Citizen's } \\
\text { Forest }\end{array}$} & \multirow{3}{*}{$\begin{array}{c}\text { Mono-layered } \\
\text { plantation }\end{array}$} & 1 & $10.4 \pm 1.4$ & $9.5 \pm 11.4$ & $75 \sim 100$ \\
\hline & & 2 & $16.0 \pm 0.6$ & $29 \pm 10.9$ & $75 \sim 100$ \\
\hline & & 3 & $11.5 \pm 0.3$ & $17 \pm 7.4$ & $75 \sim 100$ \\
\hline & \multirow{3}{*}{$\begin{array}{c}\text { Multi-layered } \\
\text { plantation }\end{array}$} & 1 & $16 \pm 3$ & $35.4 \pm 12.2$ & $51 \sim 75$ \\
\hline & & 2 & 20 & $25.7 \pm 6.1$ & $75 \sim 100$ \\
\hline & & 3 & $10.5 \pm 7.5$ & $27.6 \pm 14.6$ & $75 \sim 100$ \\
\hline
\end{tabular}


Table 5. Aboveground and belowground biomass.

\begin{tabular}{|c|c|c|c|}
\hline Parks & Vegetation type & Plot No. & Aboveground and belowground biomass $(\mathrm{kgC})$ \\
\hline \multirow{6}{*}{$\begin{array}{l}\text { Seoseoul } \\
\text { Lake Park }\end{array}$} & \multirow{3}{*}{ Mono-layered plantation } & 1 & 40.30 \\
\hline & & 2 & 75.30 \\
\hline & & 3 & 102.82 \\
\hline & \multirow{3}{*}{ Multi-layered plantation } & 1 & 116.34 \\
\hline & & 2 & 128.60 \\
\hline & & 3 & 147.78 \\
\hline \multirow{6}{*}{$\begin{array}{c}\text { Yangjae } \\
\text { Citizen's Forest }\end{array}$} & \multirow{3}{*}{ Mono-layered plantation } & 1 & 93.85 \\
\hline & & 2 & 274.29 \\
\hline & & 3 & 243.52 \\
\hline & \multirow{3}{*}{ Multi-layered plantation } & 1 & 128.49 \\
\hline & & 2 & 72.66 \\
\hline & & 3 & 221.12 \\
\hline
\end{tabular}

\section{2) Aboveground and belowground biomass}

Measurements of aboveground and belowground biomass are presented in Table 5. The average biomass in the Yangjae Citizen's Forest was higher than that in Seoseoul Lake Park. Plots 2 and 3 of the mono-layered planting area in Yangjae Citizen's Forest showed higher biomass. These plots were dominated by either Aesculus turbinata (horse chestnut) or Zelkova serrata (sawleaf zelkova), which showed larger DBH and higher planting density value. On the other hand, plot no. 1 of the Seoseoul Lake Park showed the lowest biomass and was dominated by Ulmus davidiana (elm), which showed a low DBH and low canopy enclosure value. The results illustrated that the different levels of maturity resulted in varying levels of biomass and carbon.

The highest value for above and belowground biomass was observed in the multi-layered plantation area in Seoseoul Lake Park, whereas the mono-layered plantation area in Yangjae Citizen's Forest showed the highest biomass.

\section{Soil organic carbon}

\section{1) Physical properties of soil}

The soil texture of the mono and multi-layered plantation areas in Seoseoul Lake Park was clay and sand, respectively. The soil texture of the Yangjae Citizen's Forest was humic soil. The average bulk density of each vegetation type is presented in Figure 1. The bulk density in Seoseoul Lake Park ranged from 1.43 to $1.68 \mathrm{~g} / \mathrm{cm}^{3}$, suggesting higher enclosure than that in the Yangjae Citizen's Forest, which ranged from

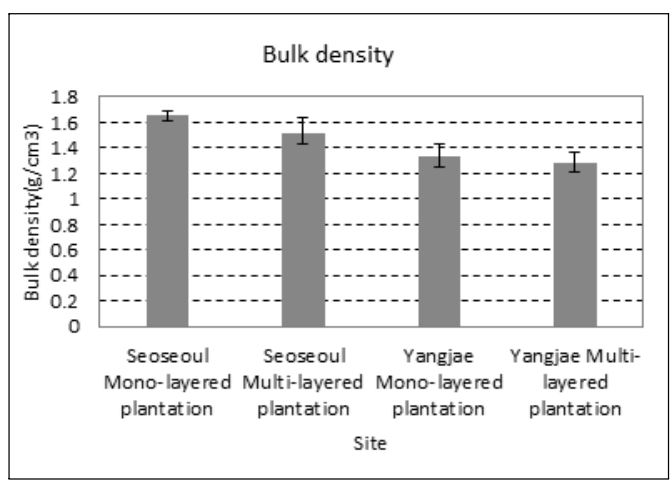

Figure 1. Bulk density. 
0.97 to $1.56 \mathrm{~g} / \mathrm{cm}^{3}$, regardless of vegetation type. This result indicated that soil texture influenced bulk density. The bulk density of the monolayered plantation areas in Seoseoul Lake Park and Yangjae Citizen's Forest ranged from 1.60 to $1.68 \mathrm{~g} / \mathrm{cm}^{3}$ and from 1.25 to $1.43 \mathrm{~g} / \mathrm{cm}^{3}$, respectively. These were higher than those of multi-layered plantation areas in both parks, which ranged from 1.43 to $1.63 \mathrm{~g} / \mathrm{cm}^{3}$ and from 1.21 to $1.36 \mathrm{~g} / \mathrm{cm}^{3}$, respectively.

It has been predicted that previous land use influences soil texture. Seoseoul Lake Park was used as a water purification plant and Yangjae Citizen's Forest used to be a farmland and village covered by garbage and mountain soil.

According to Masuda et al. (1991), soil softness could be the main contributing factor for tree growth. The results of this study showed that the multi-layered plantation area has softer soil than the mono-layered plantation area. This study also showed that higher levels of water permeability and air permeability in a multi-layered plantation area influence soil softness. These results are in line with the findings of Takahashi et al. (2000).

\section{2) Soil chemistry}

TOC, $\mathrm{pH}, \mathrm{TN}, \mathrm{CEC}$, and soil microbe values are shown in Table 6 and Figure 2. The TOC in Seoseoul Lake Park (range: 0.34-1.08\%) was higher than that in Yangjae Citizen's Forest (range: $0.16-0.7 \%$ ) possibly due to its different soil texture and low $\mathrm{pH}$. The soil $\mathrm{pH}$ of Seoseoul Lake Park ranged from 5.5 to 8.0, which was higher than that of Yangjae Citizen's Forest, which ranged from 4.8 to 5.7. The soil $\mathrm{pH}$ of Korean natural forests is generally $5.4 \pm 0.5$ (Hwang, 1973). According to the landscape design criteria (Korean Landscape Institute, 2007), the soil $\mathrm{pH}$ in Seoseoul Lake Park was within the medium range $(6.5 \sim 7.0)$, whereas that in the Yangjae Citizen's Forest was within the low range $(4.5 \sim 5.5)$.

$\mathrm{pH}$ and soil microbe levels showed opposite values. The density of soil microbes in Seoseoul Lake Park ranged from $1.95 \times 10^{4}$ to $2.9 \times 10^{5}$ $\mathrm{CFU} / \mathrm{g}$, which was higher than that of Yangjae

Table 6. Soil total organic carbon.

\begin{tabular}{|c|c|c|c|}
\hline Parks & Vegetation type & Plot No. & Total organic carbon $(\%)$ \\
\hline \multirow{6}{*}{ Seoseoul Lake Park } & \multirow{3}{*}{ Mono-layered plantation } & 1 & 0.82 \\
\hline & & 2 & 0.62 \\
\hline & & 3 & 1.08 \\
\hline & \multirow{3}{*}{ Multi-layered plantation } & 1 & 0.68 \\
\hline & & 2 & 0.82 \\
\hline & & 3 & 0.61 \\
\hline \multirow{6}{*}{ Yangjae Citizen's Forest } & \multirow{3}{*}{ Mono-layered plantation } & 1 & 0.39 \\
\hline & & 2 & 0.54 \\
\hline & & 3 & 0.70 \\
\hline & \multirow{3}{*}{ Multi-layered plantation } & 1 & 0.16 \\
\hline & & 2 & 0.50 \\
\hline & & 3 & 0.38 \\
\hline
\end{tabular}



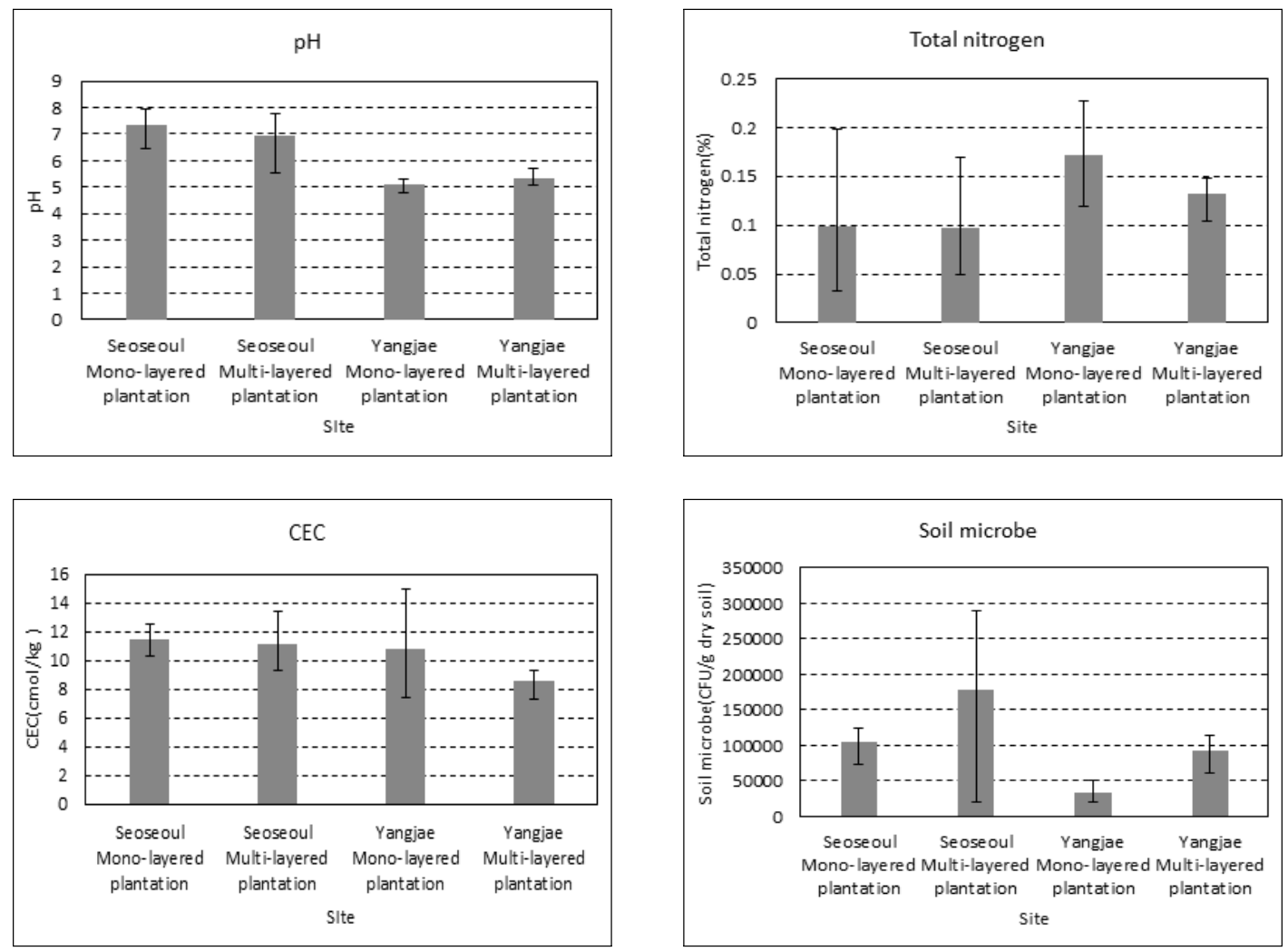

Figure 2. Soil chemistry.

Citizen's Forest, which ranged from $1.96 \times 10^{4}$ to $1.14 \times 10^{5} \mathrm{CFU} / \mathrm{g}$.

No significant relationship was observed between CEC and TOC; the CEC of Seoseoul Lake Park ranged from 9.25 to 13.39 , whereas that of Yangjae Citizen's Forest ranged from 7.35 to 14.97.

In terms of values within the same park, the TOC of the mono-layered plantation area (Seoseoul Lake Park: 0.39 1.54\%; Yangjae Citizen's Forest: $0.32 \sim 0.87 \%$ ) was higher than that of the multi-layered plantation area (Seoseoul Lake Park: $0.39 \sim 1.07 \%$; Yangjae Citizen's Forest: 0.12 $0.47 \%$ ). Contrary to the TOC values, the density of soil microbes was higher in the multi-layered plantation area than in the mono-layered plantation area.
In terms of soil TOC based on the park construction time, low $\mathrm{pH}$ was predicted to be a significant factor that influenced soil TOC in the Yangjae Citizen's Forest. Air pollution and acid rain are the main causes of soil acidification in an urban park (Lee et al., 2010), and Yangjae Citizen's Forest has been exposed to pollution for a long time since its construction. Furthermore, fertilizers are not used in the Yangjae Citizen's Forest. Therefore, in an urban park, fertilization plays an important role in the control soil $\mathrm{pH}$.

In terms of soil TOC among vegetation types, the amount of litter accumulated in the multilayered plantation area was higher than that in the mono-layered plantation area. In addition, bulk density in the multi-layered plantation area 

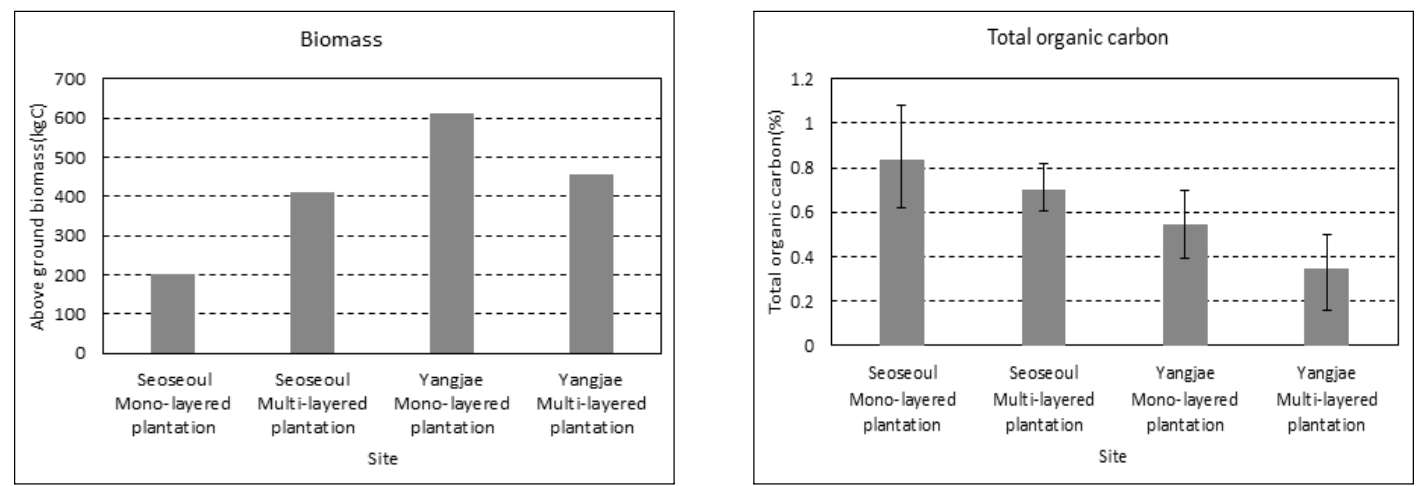

Figure 3. Comparison of biomass and soil total organic carbon.

was lower than that in the mono-layered plantation area. However in the park, soil texture, similar to water permeability and air permeability, was low due to compaction caused by park visitors. Therefore, differences in bulk density at mono and multi-layered plantation areas did not significantly influence TOC. Therefore, in an urban park, control of soil compaction can be achieved by restricting the paths that the visitors can tread.

\section{Evaluation of aboveground and belowground biomass and total soil organic carbon}

Measurements of aboveground and belowground biomass and soil TOC are shown in Figure 3. The biomass of Yangjae Citizen's Forest was higher than that of Seoseoul Lake Park, whereas soil TOC was lower in Yangjae Citizen's Forest. The mono-layered plantation area and multilayered plantation area did not show significant differences in terms of above and belowground biomass. However, the soil TOC in the monolayered plantation area was higher than that in the multi-layered plantation area. This result is in line with the findings of Zhang et al. (2011), who did not observe any particular correlation between community structure and biomass in natural forests, which is opposite to the initial hypothesis of this research. Therefore, not only biomass, but also carbon sequestration in soil, needs to be evaluated in future studies.

Limitations of this study include the small number of study plots and the exclusion of soil carbon stock measurements. Further research on soil carbon stocks using more plots is thus warranted.

\section{CONCLUSION}

Trees and soil largely influence the level of carbon sequestration in an urban area. Several studies on forest vegetation biomass and soil TOC have been conducted; however, studies involving urban parks are limited.

In this study, two hypotheses were proposed: 1) Higher biomass maturity influences TOC levels, and 2) Park construction time and plant structural diversity can influence the level of TOC. To address these hypotheses, this study compared the amounts of biomass and TOC according to vegetation type and park construction time.

The results showed that the biomass in the Yangjae Citizen's Forest was higher than that in the Seoseoul Lake Park. However, the level of TOC was lower in the Yangjae Citizen's Forest, 
which is contrary to our hypothesis. One possible reason for this discrepancy is that air pollution and acid rain may have influenced the level of soil acidity, which in turn resulted in a decrease in TOC. Water permeability and air permeability of the soil influenced the level of TOC in the mono-layered plantation area, thus, resulting in higher TOC value than that observed in the multi-layered plantation area.

In terms of long term goals, improvement in soil properties eventually results in better vegetation growth. Therefore, to improve the soil in urban parks, management by applying fertilizers such as lime, as well as effective soil compaction, is necessary. The results of this study could be used as a foundation for urban park construction and management.

\section{REFERENCES}

Baschak, L. A. and Brown, R. D. 1995. An ecological framework for the planning, design and management of urban river greenways, Landscape and urban planning. 33(2): 211-225.

Henry, M. · Tittonell, P. · Manlay. R. J. · Bernoux, M. - Albrecht, A. and Vanlauwe, B. 2009. Biodiversity, carbon stocks and sequestration potential in aboveground biomass in small holder farming systems of western Kenya. Agriculture, Ecosystems and Environment 129: 238-252.

Hunter, M. 2011. Using ecological theory to guide urban planting design: an adaptation strategy for climate change. Landscape Journal 30: $2-11$.

Hutson, M. A. 2003. Carbon management and biodiversity. Journal of Environmental Manage- ment 67: 77-86.

Hwang, Kyung-Sun. 1973. Survey on the $\mathrm{pH}$ of Soils in Korea. Journal of Korean Society of Soil Science and Fertilizer 6(3): 153-158.

Jang, Dong-su. 1995. A study on the improving direction of urban park problems by geographic information system: Seochogu Yangjae Citizen's Woods. Journal of GIS Association of Korea 3(2): 161-177.

Jo, Hyun-kil and Ahn, Tae-Won. 2000. Indicators of carbon storage and uptake by tree growth in natural ecosystem. Journal of Korean Society of Environment and Ecology 14(3): 175-182. (in Korean with English summary) Jo, Hyun-kil - Yun, Young-Hwal and Lee, Ki-Eui. 1995. Atmospheric $\mathrm{CO}_{2}$ Sequestration by Urban Greenspace: in the case of Chuncheon. Journal of Korean Institute of Landscape Architecture 23(3): 80-93. (in Korean with English summary)

Korea forest research institute. 2012. Carbon stock in urban woods. (in Korean)

Korean landscape institute. 2007. Criteria of landscape design. (in Korean)

Lee, Ho-Young $\cdot$ Oh, Choong-Hyeon $\cdot$ Kim, EunShik - Son, Yo-Whan and Park, Kwan-Soo. 2010. The vegetation and soil characteristics of urban forest as geological location in Daejeon, Korea. Journal of Korean Society of Environment and Ecology 24(5): 566-574. (in Korean with English summary)

Masuda Takuro - Morita Hitoshi and Kajita Yoshinori. 1991. Soil Condition and Growth of the Camphor trees in Sakaide Green Belt (I): Soil Condition and Root Distribution. Journal of Japanese society of revegetation technology 16(3): 11-18. (in Japanese with English summary) 
Nowak, D. J. - Crane, D. E. and Stevers, J. C. 2006. Air pollution removal by urban trees and shrubs in United States. Urban forestry and Urban Greening 4: 115-123.

Takahashi Terumasa $\cdot$ Koide Kyoko · Asano Yoshito and Kobayashi Tatsuaki. 2000. Comparison of soil fertility among different type of vegetations in an urban park "forest 21st century", Matsudo city. Journal of Japanese society of revegetation technology $25(3)$ :
196-207. (in Japanese with English summary) Watson, R. T. 2000. Land use, and forestry: A species report of the IPCC. Cambridge University Press 377.

Zhang. Y. - Duan, B. - Xian, J. and Korpelainen, H. Li. C. 2011. Links between plant diversity, carbon stocks and environmental factors along a successional gradient in a subalpine coniferous forest in Southwest China. Forest Ecology and Management 262: 361-369. 